\title{
HMGA2/RAD51B Fusion Protein
}

National Cancer Institute

\section{Source}

National Cancer Institute. HMGA2/RAD51B Fusion Protein. NCI Thesaurus. Code C99425.

A fusion protein encoded by the HMGA2/RAD51B fusion gene. This protein is comprised of the AT-hook DNA binding domain of the high mobility group protein $\mathrm{HMGI-C}$ fused to the C-terminal region of the DNA repair protein RAD51 homolog 2 protein. 